\title{
Implications for behavior of volatile elements during impacts - zinc and copper systematics in sediments from the Ries impact structure and central European tektites
}

\author{
Zuzana Rodovská ${ }^{1,2, *}$, Tomáš Magna ${ }^{1}$, Karel Žák ${ }^{3}$, Chizu Kato ${ }^{4}$, Paul S. \\ Savage $^{4,5,6}$, Frédéric Moynier ${ }^{4}$, Roman Skála ${ }^{3}$, Josef Ježek ${ }^{2}$ \\ ${ }^{1}$ Czech Geological Survey, Klárov 3, CZ-118 21 Prague 1, Czech Republic \\ ${ }^{2}$ Faculty of Science, The Charles University in Prague, \\ Albertov 6, CZ-128 43 Prague 2, Czech Republic \\ ${ }^{3}$ Institute of Geology, The Czech Academy of Sciences, \\ Rozvojová 269, CZ-165 00 Prague 6, Czech Republic \\ ${ }^{4}$ Institut de Physique du Globe de Paris, Université Paris Diderot, \\ 1 rue Jussieu, F-75005 Paris, France \\ ${ }^{5}$ Department of Earth Sciences, Durham University, \\ Science Labs, Durham DH1 3LE, United Kingdom \\ ${ }^{6}$ Department of Earth and Environmental Sciences, Irvine Building, University of St. \\ Andrews, St. Andrews, Fife, KY16 9AL, United Kingdom
}

*Corresponding author. Tel.: +420-2-5108 5102. Fax: +420-2-5181 8748.

E-mail: zuzana.rodovska@geology.cz

Word count abstract (incl. Keywords): $\quad 307$

Word count main text: 6802

Characters w/spaces (abstract, main text,

acknowledgement):

46217

Figures:

4

Tables:

2 
Abstract

Moldavites are tektites genetically related to the Ries impact structure, located in Central

Europe, but the source materials and the processes related to the chemical fractionation of moldavites are not fully constrained. To further understand moldavite genesis, the $\mathrm{Cu}$ and $\mathrm{Zn}$ abundances and isotope compositions were measured in a suite of tektites from four different sub-strewn fields (South Bohemia, Moravia, Cheb Basin, Lusatia) and chemically diverse sediments from the surroundings of the Ries impact structure. Moldavites are slightly depleted in $\mathrm{Zn}(\sim 10-20 \%)$ and distinctly depleted in $\mathrm{Cu}(>90 \%)$ relative to supposed sedimentary precursors. Moreover, the moldavites show a wide range in $\delta^{66} \mathrm{Zn}$ values between 1.7 and 3.7\% (relative to JMC 3-0749 Lyon) and $\delta^{65} \mathrm{Cu}$ values between 1.6 and $12.5 \%$ (relative to NIST SRM 976) and are thus enriched in heavy isotopes relative to their possible parent sedimentary sources $\left(\delta^{66} \mathrm{Zn}=-0.07\right.$ to $+0.64 \%$; $\delta^{65} \mathrm{Cu}=-0.4$ to $+0.7 \%$ ). In particular, the Cheb Basin moldavites show some of the highest $\delta^{65} \mathrm{Cu}$ values (up to $12.5 \%$ ) ever observed in natural samples. The relative magnitude of isotope fractionation for $\mathrm{Cu}$ and $\mathrm{Zn}$ seen here is opposite to oxygen-poor environments such as Moon where $\mathrm{Zn}$ is significantly more isotopically fractionated than $\mathrm{Cu}$. One possibility is that monovalent $\mathrm{Cu}$ diffuses faster than divalent $\mathrm{Zn}$ in the reduced melt and diffusion will not affect extent of $\mathrm{Zn}$ isotope fractionation. These observations imply that the capability of forming redox environment may aid in volatilizing some elements, accompanied by isotope fractionation, during the impact process. The larger extent of elemental depletion, coupled with isotope fractionation of more refractory $\mathrm{Cu}$ relative to $\mathrm{Zn}$, may also hinge on the presence of carbonyl species of transition metals and electromagnetic charge, which could exist in the impact-induced high-velocity jet of vapor and melts. 
Keywords: zinc isotopes; copper isotopes; tektites; Ries crater; Ries area sediments; isotope fractionation; impact; volatile loss 
Tektites are terrestrial silica-rich glasses produced during hypervelocity impacts of an extraterrestrial projectile onto the Earth's surface (Koeberl, 1994, 2014; Artemieva, 2008) and as such, they represent a unique source of information about conditions and processes occurring during early phases of the impact process. The close similarity between the chemical composition of the Earth's surface sediments and tektites implies that tektites were formed by reworking of such target materials, mostly from the uppermost unconsolidated strata (e.g., Shaw and Wasserburg, 1982; Koeberl and Fredriksson, 1986; Blum et al., 1992; Dressler and Reimold, 2001; Řanda et al., 2008; Skála et al., 2009; Stöffler et al., 2013; Žák et al., 2016). At present, four major geographically distinct tektite strewn fields are recognized: North American, Central European, Ivory Coast and Australasian. The Central European tektites (moldavites) are assumed to have been formed by reworking of the chemically and mineralogically variable sediments of the Upper Freshwater Molasse (Obere Süßwassermolasse, OSM; e.g., Luft, 1983; von Engelhardt et al., 1987, 2005; Žák et al., 2016). The Ries impact structure (centered close to Nördlingen, south-eastern Germany) is accepted as the parent crater to moldavites, based on the excellent concordance of their ages at ca. $14.75 \pm 0.20 \mathrm{Ma}$ (e.g., Buchner et al., 2010; Schwarz and Lippolt, 2014). However, the agreement between the chemical composition of the OSM sediments and moldavites is not excellent, which was explained as a result of chemical modifications during the process of tektite formation (von Engelhardt et al., 2005; Žák et al., 2016).

Zinc (lithophile) and $\mathrm{Cu}$ (chalcophile) both are volatile/moderately volatile elements (Lodders, 2003). Chondrites are significantly enriched in Zn compared with the Bulk Silicate Earth (BSE) and Mars (McDonough and Sun, 1995; Barrat et al., 2012; Paniello et al., 2012a) while both the Moon and the howardite-eucrite-diogenite (HED) meteorites from asteroid 4- 
Vesta are depleted in Zn (Paniello et al., 2012a; Paniello et al., 2012b), implying planetaryscale processes leading to sizeable loss of $\mathrm{Zn}$, perhaps caused by giant collisions, thermal metamorphism and/or cataclysmic bombardment (Day and Moynier, 2014). Previously published $\mathrm{Zn}$ concentrations in tektites revealed a significant range with a particular difference among individual strewn fields (7-283 ppm; Koeberl, 1992; Koeberl et al., 1997; Moynier et al., 2009a; Skála et al., 2009) and high $\delta^{66 / 64} \mathrm{Zn}$ values from $0.2 \%$ to $2.5 \%$ (per mil deviation of the ${ }^{66} \mathrm{Zn} /{ }^{64} \mathrm{Zn}$ ratio from the JMC 3-0749L standard), when compared to the average upper continental crust ( $\delta^{66 / 64} \mathrm{Zn}$ from $0 \%$ to $0.7 \%$; Albarède, 2004; Chen et al., $2013)$ and Bulk Silicate Earth $\left(\delta^{66 / 64} \mathrm{Zn}_{\mathrm{BSE}}=0.30 \pm 0.03 \%\right.$; Moynier et al., 2011; Chen et al., 2013; Doucet et al., 2016; Wang et al., 2017). Most tektites analyzed previously show an average $\mathrm{Cu}$ content of only $2 \pm 1 \mathrm{ppm}$ and are significantly enriched in heavy $\mathrm{Cu}\left(\delta^{65} \mathrm{Cu}\right.$ values between 2 and 7\%, relative to NIST 976; Moynier et al., 2010) which is in contrast to the results of Li et al. (2009), Liu at el. (2015) and Savage et al. (2015) which, in general, attest to a homogeneous $\mathrm{Cu}$ isotope composition of terrestrial igneous lithologies $(0.08 \pm 0.17 \%$; Moynier et al., 2017) as well as clastic sediments $(0.08 \pm 0.20 \%$; Moynier et al., 2017). Because tektites suffer from minor $\mathrm{Zn}$ loss but significant $\mathrm{Cu}$ depletion (Moynier et al., 2009a; Moynier et al., 2010; Žák et al., 2016), the impact processes can potentially be used as a proxy for the loss of volatile species during planetary formation.

Here, we present new $\mathrm{Cu}-\mathrm{Zn}$ isotope data for the set of well-characterized moldavites from the Czech Republic and Germany, and chemically diverse sediments from the close surroundings of the Ries impact structure (Žák et al., 2016) in order to provide further constraints on (i) $\mathrm{Zn}$ and $\mathrm{Cu}$ elemental and isotope variability in possible tektite source materials that could be linked to the heterogeneity of their bulk chemistry, and (ii) the extent of $\mathrm{Zn}$ and $\mathrm{Cu}$ isotope fractionation between the plausible source sediments and tektites. The latter has been only marginally studied for $\mathrm{Zn}$, with the Ivory Coast strewn field displaying a 
$\delta^{66 / 64} \mathrm{Zn}$ offset $>1 \%$ between the Bosumtwi crater rocks, having crustal $\mathrm{Zn}$ isotope signature, and isotopically heavier Ivory Coast tektites (Moynier et al., 2009a). Moreover, there may be a difference between Bosumtwi and Ries in the quantity of volatiles (in particular water) in the surface layer of the target materials (crystalline versus loosely bound; Koeberl et al., 1998; Žák et al., 2016) which may play a key role in effective fragmentation of molten tektite glass due to the escape of volatile species (see recent model of Žák et al., 2016) and the attainment of conditions suitable for $\mathrm{Zn}$ and $\mathrm{Cu}$ loss and related isotope fractionation.

\section{Samples and analytical techniques}

In this study, 13 samples of moldavites from four distinct sub-strewn fields of the Central European tektite field and 16 samples of sediments from surrounding of the Ries, characterized previously with respect to their major and trace element chemistry, physical properties (shape, color and sculpture) and Li elemental/isotope systematics (Řanda et al., 2008; Skála et al., 2009; Skála et al., 2010; Řanda et al., 2014; Rodovská et al., 2016; Žák et al., 2016), were analyzed for $\mathrm{Zn}$ and $\mathrm{Cu}$ abundance and isotope compositions. Details on the general chemistry of moldavites can be found elsewhere (e.g., Bouška et al., 1973; von Engelhardt et al., 1987, 2005; Meisel et al., 1997; Trnka and Houzar, 2002; Řanda et al., 2008; Skála et al., 2009; Magna et al., 2011; Žák et al., 2016). The studied sediment samples were previously characterized with respect to their chemistry and mineralogy (Žák et al., 2016). They comprise OSM sediments with variable proportions of fine-grained (clay) fraction and sand fraction, and with variable proportions of quartz and other minerals in the sand fraction (Table 1). Several samples which could have been also present at the surface during the impact were also included (sedimentary fill of paleokarst depressions rich in limestone weathering residual minerals; freshwater Oligocene limestone). Sediment sample 
locations, descriptions, chemical and mineralogical characteristics are given in Žák et al. (2016). It should be noted that the exact morphology and sedimentary cover conditions of the target area itself are unknown, because they were completely destroyed by the impact. Therefore, the studied sediments represent only an approximation of the conditions and materials of the intrinsic target area. In addition, three samples of clay-size fractions, isolated from sedimentary samples using a common sedimentation method in distilled water were measured (we note that these fractions are not completely pure clay fractions but may contain a small proportion of other minerals including secondary phases, such as secondary Fe and Mn oxides/hydroxides). The procedure to prepare samples for clay minerals identification involved extensive washing in distilled water and separation of the clay fraction in the Andreasen cylinder. To determine bulk mineral composition X-ray diffraction patterns have been acquired from untreated bulk specimens between 3 and $70^{\circ} 2 \Theta\left(\mathrm{CuK} \alpha_{1}\right.$ radiation). The specimens have been scanned with a diffractometer between 2 and $40^{\circ} 2 \Theta$ and then saturated with ethylenglycol for 4 hours at $80^{\circ} \mathrm{C}$. Following saturation the new set of X-ray diffraction data has been acquired. After that, the glass sample wafers with specimens have been heated at $550^{\circ} \mathrm{C}$ under ambient atmosphere for 1 hour. In general, clay mineral composition is similar in all samples with subtle differences among individual sediments. Identified clay minerals include kaolinite, illite, chlorite, montmorillonite and interstratified illite/montmorillonite.

The analytical procedures for $\mathrm{Zn}$ and $\mathrm{Cu}$ purification were performed in the CAGE laboratories, the Institut de Physique du Globe de Paris (IPGP). Zinc was isolated and purified by a two-stage HBr-based anion exchange chromatography following methods given elsewhere (Moynier et al., 2006; Moynier and Le Borgne, 2015). A single-stage anion exchange chromatography for $\mathrm{Cu}$ purification using AG-MP1 resin was employed (Maréchal et al., 1999; Savage et al., 2015) with $95-100 \%$ recovery; the total procedural blank for $\mathrm{Cu}$ was $\sim 4 \mathrm{ng}$. The $\mathrm{Zn}$ and $\mathrm{Cu}$ concentrations and isotope compositions were measured by 
standard-sample bracketing (Maréchal et al., 1999; Moynier et al., 2006, 2009a, 2010; Savage et al., 2015) using a Neptune Plus multiple-collector inductively-coupled-plasma mass spectrometer (MC-ICPMS; ThermoFisher, Bremen, Germany), housed at IPGP. The 2SD on repeated measurements of the bracketing standard was $\pm 0.06 \%$; for multiple dissolutions and purifications of BHVO-2, the $2 \mathrm{SD}$ uncertainty was $\pm 0.08 \%$. Zinc and $\mathrm{Cu}$ concentrations were determined against a $100 \mathrm{ppb}$ Zn reference solution (JMC 3-0749 Lyon) and a 50 ppb NIST SRM 976 reference solution, respectively. Zinc isotope compositions were calculated as $\delta^{\times} \mathrm{Zn}$ $(\%)=\left[\left({ }^{\times} \mathrm{Zn} /{ }^{64} \mathrm{Zn}\right)_{\text {sample }} /\left({ }^{\times} \mathrm{Zn} /{ }^{64} \mathrm{Zn}\right)_{\text {standard }}-1\right] \times 1000$, where ${ }^{\times} \mathrm{Zn}$ denotes ${ }^{66} \mathrm{Zn},{ }^{67} \mathrm{Zn}$ and ${ }^{68} \mathrm{Zn}$, respectively. Potential interferences from ${ }^{23} \mathrm{Na}^{40} \mathrm{Ar}^{+}$and ${ }^{25} \mathrm{Mg}^{40} \mathrm{Ar}^{+}$on ${ }^{63} \mathrm{Cu}$ and ${ }^{65} \mathrm{Cu}$, respectively, were ruled out by measuring $\mathrm{Na} / \mathrm{Cu}$ and $\mathrm{Mg} / \mathrm{Cu}$ ratios in the samples prior to the isotope analysis. Isotope ratios of $\mathrm{Cu}$ are expressed as $\delta^{65} \mathrm{Cu}(\%)=$ $\left[\left({ }^{65} \mathrm{Cu} /{ }^{63} \mathrm{Cu}\right)_{\text {sample }} /\left({ }^{65} \mathrm{Cu} /{ }^{63} \mathrm{Cu}\right)_{\text {standard }}-1\right] \times 1000$. Reference rock standards BCR-2 and BHVO2 (US Geol. Surv.) were processed and analyzed along with the unknown samples to monitor the accuracy and reproducibility of the analytical procedures and spectrometry routines; their $\mathrm{Zn}$ and $\mathrm{Cu}$ isotope compositions were consistent with previous studies (Table $\mathbf{1}$ and Archer and Vance, 2004; Moynier et al., 2010; Moeller et al., 2012; Chen et al., 2013; Sossi et al., 2014; Savage et al., 2015; Lv et al., 2016).

\subsection{Zinc abundance and isotope compositions}

\section{Results}

The $\mathrm{Zn}$ concentrations and isotope ratios in moldavites, sediments and clay fractions are reported in Table 1 and plotted in Fig. 1. The moldavites show a wide range in $\mathrm{Zn}$ abundance (1.9-108 ppm), extending to both lower and higher $\mathrm{Zn}$ contents compared with data from 
Moynier et al. (2009a), which may reflect the wider chemical range of moldavites selected for this study (see Skála et al., 2009). Moldavites from South Bohemia have 1.9-34.5 ppm Zn, those from Moravia have 7.3-18.8 ppm $\mathrm{Zn}$ and those from the Cheb Basin contain 20.6-108 ppm $\mathrm{Zn}$ (with three out of four samples having $[\mathrm{Zn}]>58 \mathrm{ppm}$ ); a single moldavite from Lusatia has $16.7 \mathrm{ppm} \mathrm{Zn}$. These results attest to modest differences between the Cheb Basin moldavites and those from the other sub-strewn fields, noted by Řanda et al. (2008) and Skála et al. (2009). The Ries sediments show a remarkable range in $\mathrm{Zn}$ abundances from 4.6 to 186 ppm Zn. Zinc contents in sediments correlate with $\mathrm{Al}_{2} \mathrm{O}_{3}$ contents (Fig. 2) and $\mathrm{FeO}$ (not shown). Zinc contents obtained in this study are broadly consistent with those reported by Žák et al. (2016) for different aliquots of the same samples of moldavites and sediments, with the exception of slightly lower Zn contents in high-Zn samples reported in this study. The clay fractions from three sediments (1 UTZ, $10 \mathrm{GLM}, 13 \mathrm{BMB}$ ) have from 94 to $161 \mathrm{ppm} \mathrm{Zn;} \mathrm{this}$ is, in all three cases, higher than $\mathrm{Zn}$ abundance in the respective bulk sample, in case of sample 13 BMB by a factor of three (Table $\mathbf{1}$ ).

The moldavites in this study show a range in $\delta^{66} \mathrm{Zn}=1.7-3.7 \%$, which is significantly larger compared to data reported by Moynier et al. (2009a) for four south Bohemian specimens $\left(\delta^{66} \mathrm{Zn}=1.9-2.3 \%\right)$. The moldavites from different sub-strewn fields do not show distinct $\mathrm{Zn}$ isotope compositions (Moravia: $\delta^{66} \mathrm{Zn}=2.1-2.7 \%$; Lusatia: $\delta^{66} \mathrm{Zn}=2.5 \%$; South Bohemia: $\delta^{66} \mathrm{Zn}=1.7-3.3 \%$; the Cheb Basin: $\delta^{66} \mathrm{Zn}=2.0-3.7 \%$ ). The sediments from the Ries surroundings show little variability in $\delta^{66} \mathrm{Zn}$ values $(-0.07 \%$ to $0.64 \%$, which is consistent with global data for sediments (see recent review byMoynier et al., 2017). The clay fractions always have lighter $\mathrm{Zn}$ isotope compositions than the corresponding bulk sediments,

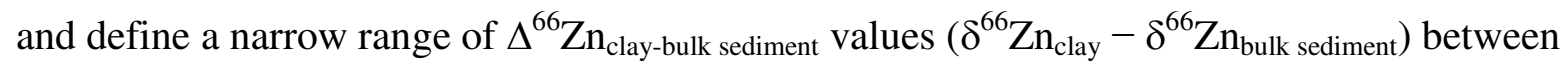
-0.5 and $-0.7 \%$, indicating preferential incorporation of light $\mathrm{Zn}$ isotopes into clay. 


\subsection{Copper abundance and isotope compositions}

The $\mathrm{Cu}$ contents and isotope compositions are listed in Table 1 and plotted in Fig. 1. The moldavites show a range in $\mathrm{Cu}$ abundance from 0.2 to $2.9 \mathrm{ppm}$ (the values were taken from Žák et al., 2016), much lower than the canonical abundance of the upper continental crust at 28 ppm (Rudnick and Gao, 2014). Moldavites from South Bohemia have 0.2-1.4 ppm Cu, those from Moravia have 0.6-0.8 ppm $\mathrm{Cu}$ and those from the Cheb Basin have 0.4-2.9 ppm $\mathrm{Cu}$; a single Lusatian moldavite has $1.1 \mathrm{ppm} \mathrm{Cu}$. These values are consistent with those found by Skála et al. (2009) for the Cheb Basin moldavites (0.9 to $4.7 \mathrm{ppm})$ as well as for other tektite fields, with the exception of low $\mathrm{Cu}$ contents for moldavites $(<0.4 \mathrm{ppm})$ reported by Moynier et al. (2010). The Ries sediments show a range in $\mathrm{Cu}$ concentrations from 0.8 to 58 ppm $\mathrm{Cu}$; these values are consistent with those reported by Žák et al. (2016). The clay fractions from three sediments have from 21.4 to $42.2 \mathrm{ppm} \mathrm{Cu}$ which is in all three cases higher than $\mathrm{Cu}$ content in the respective bulk sediment, and is consistent with the findings for $\mathrm{Zn}$.

The moldavites from South Bohemia have $\delta^{65} \mathrm{Cu}$ values from 2.2 to 5.4\%, those from Moravia between 5.8 and 8.8\%o and those from the Cheb Basin between 1.6 and 12.5\%; a single Lusatian moldavite has $\delta^{65} \mathrm{Cu}$ of $6.1 \%$. The new $\delta^{65} \mathrm{Cu}$ values measured for moldavites extend towards significantly heavier values than those reported previously (Moynier et al., 2010), with the Cheb Basin moldavites showing some of the highest $\delta^{65} \mathrm{Cu}$ values (up to $12.5 \%$ ) ever observed in natural high-temperature modified samples. The largest previously reported natural ${ }^{65} \mathrm{Cu}$ enrichments were observed in strongly weathered shales from central China (up to $19.7 \%$; Lv et al., 2016) and secondary $\mathrm{Cu}$ minerals associated with ore body formation, where $\delta^{65} \mathrm{Cu}$ values are typically positive in the supergene, and can reach $\sim 10 \%$ o (e.g., Rouxel et al., 2004; Mathur et al., 2009). The $\delta^{65} \mathrm{Cu}$ values in the Ries area sediments 
show a narrow variation $(-0.4$ to $0.7 \%)$ and are in the range of common crustal lithologies (Luck et al., 2003; Li et al., 2009). The clay fractions show a range in $\delta^{65} \mathrm{Cu}$ values between -0.1 and $+0.2 \%$ and are, contrary to $\mathrm{Zn}$, isotopically heavier than the respective bulk sediments $\left(\Delta^{65} \mathrm{Cu}_{\text {clay-bulk sediment }}\right.$ values between 0.01 and $0.21 \%$ ).

\section{Discussion}

\subsubsection{Statistical evaluation of $\mathrm{Zn}$ isotope data - implications for isotope fractionation in natural processes}

\section{It has been discussed that kinetic effects may become an important factor in forming} measurable isotope fractionation effects. For example, (Young and Galy, 2004) raised this possibility for $\mathrm{Mg}$ isotopes although the resolution of equilibrium and kinetic fractionation processes in the three-isotope $\mathrm{Mg}$ plot seems to be barely outside of the statistical resolution. Applying the approach of (Young and Galy, 2004) to Zn, the calculated theoretical slopes $\beta=$ 1.942 and 1.972 for equilibrium and kinetic fractionation, respectively, suggest that these two different mechanisms of $\mathrm{Zn}$ isotope fractionation could be resolved in nature. With the given data set we were able to test this hypothesis for $\mathrm{Zn}$ isotopes. In the triple- $\mathrm{Zn}$ isotope plot (Fig. 3), both $x$-y variables (i.e., $\delta^{66} \mathrm{Zn}$ and $\delta^{68} \mathrm{Zn}$ ) can be considered as random, containing measurement errors and other variability. Such cases are referred to as structural or model II regression. A very simple structural relationship is assumed to be hidden in our data in the form of a line with theoretically known slope. The SMATR package (Falster et al., 2006; Warton et al., 2006) provides the possibility of fitting bivariate lines using the major axis (MA) or standardized major axis (SMA). 
In the present study, we defined three separate groups, sediments (S), moldavites from this study (M), and other published tektites (T). The results of fitting MA lines, paralleled by 95\% confidence intervals, are listed in Table 2 . Because the basic assumption for MA regression is the bivariate normality, we have inspected whether the S, M and T group data are approximately bivariate normal, and applied the normality tests. For the group $\mathrm{M}$, the normality assumption was violated and two samples SBM-192 and SBM-44 were excluded from further statistical evaluation. The former sample represents only a single measurement and averaging of several independent measurements was therefore not possible, while the latter is an average of three measurements all of which deviated outside the pattern of the individual measurements of the other samples in this study. The cleaned data were denoted as M1 (SBM-192 excluded) and M2 (both SBM-192 and SBM-44 excluded), and the results for all the three variants of moldavite data (M, M1, and M2) are listed in Table 2. Furthermore, a bootstrap (by resampling residuals) was applied to compute confidence intervals for the slopes and elevations for comparison. A good agreement of the computed slopes $b$ with the theoretical ones ( $\beta=1.942$ for sediments, and 1.972 for moldavites and other tektites), is observed with all confidence intervals containing the theoretical values. In case of groups M1 and M2 the confidence intervals are narrower. The computed intercepts $a$ are close to zero with a larger difference for the group M.

As the lines for all groups should pass through the origin, we have also used MA regression with zero intercept (i.e., with the line forced through the origin). For the group $\mathrm{M}$ the theoretical slope (1.972) is not in the $95 \%$ confidence interval, implying statistically significant difference. Due to violation of the normality assumption for the group $\mathrm{M}$, the cleaned data M1 and M2 reveal an agreement with the theoretical slope. For the group T, the regression with zero intercept shows a significant difference from the theoretical slope. The reasons for this difference are unknown but some inter-laboratory differences could perhaps 
be involved. We tested several inter-group comparison hypotheses using SMATR. (i) By comparing S and M (M1, M2) groups only (i.e., data from this study measured in the same laboratory), the test for common slope did not reject the hypothesis that slopes are equal ( $p=$ $0.082,0.226,0.384$ ). (ii) The test for particular slope did not reject the hypothesis that the common slope of other tektites (T) and moldavites M (M1, M2) is equal to $1.97(p=0.071$, 0.141, 0.165). (iii) The test for common slope did not reject the hypothesis that slopes of all S, M (M1, M2), and T are equal ( $p=0.066,0.092,0.085)$. Collectively, the detailed statistical treatment indicates that a significant statistical difference between sediments and tektites was not proven (Fig. 3) but in some cases, this hypothesis was close to rejection (Table 2). Such a conclusion leaves the question of possible resolution of $\mathrm{Zn}$ isotope fractionation during kinetic and equilibrium processes unsolved. It may be that this subtle difference may only become apparent at $\mathrm{Zn}$ isotope compositions that are much beyond the range of common terrestrial as well extra-terrestrial values.

\subsection{Zinc and copper systematics in the Ries area sediments}

The $\delta^{66} \mathrm{Zn}$ variation in common terrestrial crustal igneous rocks is, in general, limited to between $\sim 0$ and $0.6 \%$ (Maréchal et al., 1999; Chen et al., 2013), and can be up to $0.7 \%$ in sedimentary rocks (Pichat et al., 2003; Albarède, 2004; Mason et al., 2005). This is paralleled by moderately high $\mathrm{Zn}$ abundance in the upper continental crust (67 \pm 6 ppm; Rudnick and Gao, 2014) compared with $55 \mathrm{ppm}$ in the primitive upper mantle (McDonough and Sun, 1995), and between 20 and 200 ppm in different granite types (I, S, A; (Hall, 1975; Chappell and White, 1992; King et al., 1997). These findings are consistent with uniform $\mathrm{Zn}$ isotope composition of the bulk Ries sediments in this study (Fig. 1) with $\delta^{66} \mathrm{Zn}$ constrained between -0.07 and $0.64 \%$. On the other hand, $\mathrm{Zn}$ contents in sediments from the Ries vary 
significantly by a factor of $\sim 40$ which, together with the variability of $\mathrm{Zn}$ contents of moldavites, attests to a compositional variability of the target materials and incorporation of chemically distinct sedimentary lithologies that ultimately led to the formation of moldavites (e.g., von Engelhardt et al., 1987; Rodovská et al., 2016; Žák et al., 2016). The apparently higher $\mathrm{Zn}$ contents in the Cheb Basin moldavites suggest that specific sediments must have been sourced which also have higher $\mathrm{Fe}$ and $\mathrm{Al}$ abundances (Fig. 2). The paleogeography indicates that the northern boundary of the OSM sediments occurred in the target area (e.g., Pohl et al., 1977; Hörz et al., 1983). Uneven karst surface with residual karst sediments could have been present in the northern part of the target area. This type of material, represented by the samples 14 BMB, 24 RTS and 25 RTS, shows distinctly higher Zn contents (>118 ppm), paralleled by elevated abundances of $\mathrm{Cu}, \mathrm{Al}$, and $\mathrm{Fe}$. Their participation in the ultimate source of materials for moldavites of the Cheb Basin area, carrying elevated $\mathrm{Zn}$ contents, is therefore probable (see also Rodovská et al., 2016).

Typical $\mathrm{Cu}$ contents in continental crustal lithologies vary greatly ( $28 \mathrm{ppm}$ in the bulk continental crust, $\sim 118$ ppm in shales, 20 ppm in soils; Jeng, 1992; McDonough and Sun, 1995; Bigalke et al., 2011; Rudnick and Gao, 2014) while ultramafic mantle rocks have 20-30 ppm Cu (McDonough and Sun, 1995; Palme and O'Neill, 2014). The effusive and intrusive igneous rocks from the Earth's mantle and crust, such as basalts and granites, typically have invariant $\delta^{65} \mathrm{Cu}$ values of $\sim 0 \%$ (Luck et al., 2003; Archer and Vance, 2004; Li et al., 2009; Savage et al., 2015), and the weighted mean $\delta^{65} \mathrm{Cu}$ of continental sediments of $\sim 0 \%$ attests to insignificant $\mathrm{Cu}$ isotope fractionation during weathering (note a restricted range in $\delta^{65} \mathrm{Cu}$ between $-0.57 \%$ and $0.44 \%$ found for different soil horizons; Bigalke et al., 2011). In contrast, recent data of $\mathrm{Lv}$ et al. (2016) reveals extreme fractionation of Cu isotopes during chemical weathering, with $\delta^{65} \mathrm{Cu}$ values ranging between -6.4 and $19.7 \%$. This is underscored by significant $\mathrm{Cu}$ isotope fractionations reported for oxidative weathering of 
primary sulphides $\left(0.0\right.$ to $+2.0 \%{ }^{65} \mathrm{Cu}_{\text {solution-chalcopyrite rock }}$ Fernandez and Borrok, 2009;

Mathur et al., 2012), as well as during sorption on Fe-oxides and organic complexation (Fernandez and Borrok, 2009). Lithologically diverse sediments in this study show a range in $\mathrm{Cu}$ concentrations between 0.9 and $58 \mathrm{ppm}$ (Table 1) that are well correlated with $\mathrm{Zn}$ contents (only the sample $15 \mathrm{HRD}$ shows elevated $\mathrm{Cu}$ abundance at a given $\mathrm{Zn}$ content; Fig. 1a). The broad $\mathrm{Zn}-\mathrm{Cu}$ isotope co-variation observed for sediments from surroundings of the Ries (Fig. 1b) also indicates a similar sense of stable isotope fractionation of chalcophile elements during weathering of common silicate lithologies despite the possibility that $\mathrm{Zn}$ and $\mathrm{Cu}$ might be accommodated in different phases in the source rocks of sediments and in the secondary minerals. The contents of $\mathrm{Cu}$ in sediments correlate with $\mathrm{FeO}, \mathrm{Al}_{2} \mathrm{O}_{3}$ and suggest higher $\mathrm{FeO}$ and $\mathrm{Al}_{2} \mathrm{O}_{3}$ content in possible parent sediments. This would indicate somewhat different behavior of $\mathrm{Zn}$ and $\mathrm{Cu}$ during weathering in the sense that these elements would be isotopically fractionated in the opposite direction during formation of clay minerals. This means that (i) the formation of unconsolidated materials through weathering imparts rather minor isotope effects to both $\mathrm{Zn}$ and $\mathrm{Cu}$, (ii) the behavior of $\mathrm{Cu}$ and $\mathrm{Zn}$ during tektite formation is not completely identical, and (iii) strong isotope effects observed for tektites (see Section 4.3) must solely be linked to conditions existing during or shortly after the impact.

\subsubsection{Behavior of $\mathrm{Zn}$ and $\mathrm{Cu}$ at low temperatures}

Primary and secondary mineralogy can play a determining role in the stable isotope systematics of sedimentary units although for many isotope systems the experimental data and/or natural observations are insufficient or absent. Clay fractions isolated from bulk sediments are uniformly enriched in $\mathrm{Cu}$ and $\mathrm{Zn}$ relative to the corresponding bulk sediments despite the compositional diversity (clay-rich, quartz sand-rich, limestone weathering 
residuum), attesting to similar behaviour of $\mathrm{Cu}$ and $\mathrm{Zn}$ at low temperatures, although adsorption of heavy metals may differ upon variable chemical and physical conditions (e.g., Young Do and Park, 2011; Helios-Rybicka and Wójcik, 2012). The enrichment of $\mathrm{Cu}$ and $\mathrm{Zn}$ is most apparent for the low-[Cu]-[Zn] sample $13 \mathrm{BMB}$ with an enrichment factor in the clay fraction of $>2$ and $\sim 3$ for $\mathrm{Cu}$ and $\mathrm{Zn}$, respectively. Notable differences are, however, observed for $\mathrm{Zn}$ and $\mathrm{Cu}$ isotope systematics in clay fractions. Zinc isotope compositions are significantly lighter in clays relative to the corresponding bulk sediments which is in contrast to the findings of Guinoiseau et al. (2016) who observed a systematic enrichment in heavy $\mathrm{Zn}$ isotopes on the surface of kaolinite ( $\Delta^{66} \mathrm{Zn}_{\text {adsorbed-solution from } 0.11 \% \text { to } 0.49 \% \text { ). }}$.

$\mathrm{Cu}$ isotopes in clay fractions show zero to slight enrichments in ${ }^{65} \mathrm{Cu}$. This indicates a mineralogy-mediated dichotomy in generating intra-sample $\mathrm{Zn}-\mathrm{Cu}$ isotope variations, which may perhaps reflect occupation at different crystal sites for $\mathrm{Zn}$ and $\mathrm{Cu}$. Still, $\delta^{66} \mathrm{Zn}$ values in clay fractions are similar to those reported for global clays (e.g., Maréchal et al., 2000). Interestingly, the recent experimental study of Li et al. (2015) showed the opposite sense of $\mathrm{Cu}$ isotope fractionation during adsorption onto kaolinite where the $\Delta^{65} \mathrm{Cu}_{\text {kaolinite-solution }}$ of $-0.17 \pm 0.10 \%(2 \sigma)$ appears to invoke preferential incorporation of isotopically light $\mathrm{Cu}$ into clays, perhaps as a result of sorption of free $\mathrm{Cu}$ ion onto the surface of clay mineral. Li et al. (2015) concluded that the isotope compositions of $\mathrm{Cu}$ adsorbed onto natural soils may vary greatly at relatively low $\mathrm{Cu}$ concentrations of the soil solutions. This is underscored by a large variation in $\delta^{65} \mathrm{Cu}$ from -17 to $+10 \%$ that was observed in secondary mineral phases which typically develop during weathering of sulphides in the near-surface environment (Mathur et al., 2009). These observations indicate that clay minerals of the OSM sediments cannot form a major part of the moldavite melts because they are distinctly enriched in $\mathrm{Zn}$, and, at the same time, they carry a resolvedly light $\mathrm{Zn}$ isotope signature (Fig. 1). Moreover, they also have too much $\mathrm{Al}$ and not enough $\mathrm{Si}$ so that their theoretically elevated proportion would violate major 
element constraints because only the sands (containing abundant mica, feldspar, etc.) with a moderate clay admixture and a very small content of clastic (mainly dolomitic) carbonates are suitable for moldavite production (von Engelhardt et al., 1987; Žák et al., 2016).

\subsection{Zinc and copper systematics in moldavites - implications for the impact processes}

Several stable isotope systems have been studied previously (Humayun and Clayton, 1995; Wombacher et al., 2003; Moynier et al., 2009a, 2010; Magna et al., 2011; Rodovská et al., 2016 in order to test the possible isotope fractionations related to extreme physical conditions existing during the hypervelocity impact events. For example, Moynier et al. (2009a) have found large variations for $\mathrm{Zn}$ isotopes $\left(\delta^{66} \mathrm{Zn}=0.3-2.5 \%\right)$, and the differences in $\delta^{66} \mathrm{Zn}$ among moldavites, Ivory Coast tektites, Australasian tektites (including Muong Nong-type tektites), and bediasites (North American tektite field) were explained as a result of evaporation in the context of shock heating. However, the $\mathrm{p}-\mathrm{T}$ conditions of individual impacts and the pre-impact chemical and lithological situation may be largely different, which could perhaps be reflected in variable $\mathrm{Zn}$ isotope systematics of tektites from individual strewn fields. In a follow-up study, Moynier et al. (2010) explored $\mathrm{Cu}$ elemental and isotope systematics in tektites and have shown that (i) $\mathrm{Cu}$ in tektites was significantly more depleted than $\mathrm{Zn}$, and (ii) tektites displayed a significantly larger range in $\delta^{65} \mathrm{Cu}$ than in $\delta^{66} \mathrm{Zn}$ (reflected in larger \%o/amu variation) despite higher half mass condensation temperature of $\mathrm{Cu}$ compared to $\mathrm{Zn}$. Indeed, Albarede et al. (2007) noted that $\mathrm{Cu}$ is isotopically more fractionated (up to $0.8 \%$ ) than $\mathrm{Zn}$ (up to $0.4 \%$ ) in shocked sandstones from the Meteor Crater, USA. This could, in part, result from the differences in ionic radii of $\mathrm{Zn}^{2+}$ and $\mathrm{Cu}^{+}$ which translates into different diffusion coefficients of these ions in silicate melts (see discussion in Moynier et al., 2010). Highly reducing conditions of the impact systems have 
been documented by the predominance of $\mathrm{Fe}^{2+}$ over $\mathrm{Fe}^{3+}$ in moldavites (e.g., Dunlap et al., 1998; Skála et al., 2009) or reduced gaseous species (Žák et al., 2012), while in the source sediments this relationship is opposite; the existence of $\mathrm{Cu}^{+}$rather than $\mathrm{Cu}^{2+}$ compositions is therefore likely during tektite-forming events. Wombacher et al. (2003) have found significant enrichments in heavy Cd isotopes in one investigated Muong Nong-type tektite caused probably by evaporative loss whereas other terrestrial materials have shown no or very minor variation in $\delta^{112 / 114} \mathrm{Cd}$. Combined studies of Li systematics in central European tektites and possible target sediments from the Ries (Magna et al., 2011; Rodovská et al., 2016) indicated that neither is Li lost during the impact event nor are Li isotopes fractionated significantly by shock heating and flash melting. Moreover, it appears that Li is homogenized effectively in tektites despite a large range in Li contents and isotope compositions of target sediments. Studies of somewhat more volatile potassium (Humayun and Clayton, 1995; Herzog et al., 2008) are consistent with a limited loss of some elements from a molten glass into the vapor/plasma although energetic collisions may fractionate $\mathrm{K}$ isotopes (Wang and Jacobsen, 2016).

In contrast to sediments (Section 4.2), all tektites measured in the present study are distinctly enriched in the heavy isotopes of $\mathrm{Zn}$ and $\mathrm{Cu}$ (Fig. 1b), consistent with earlier results (Moynier et al., 2009a, 2010). The only other natural samples known so far to have comparably heavy $\mathrm{Zn}$ isotope compositions are lunar regolith samples $\left(\delta^{66} \mathrm{Zn}\right.$ up to $6.4 \%$; Moynier et al., 2006; Paniello et al., 2012a; Kato et al., 2015), EL6 enstatite chondrites and eucrites (Moynier et al., 2011; Paniello et al., 2012b) although not all of these high- $\delta^{66} \mathrm{Zn}$ samples suffered from a resolvable Zn loss. In particular, Hvittis, Atlanta and North West Forrest EL6 enstatite chondrites have $\delta^{66} \mathrm{Zn}$ values up to $7.4 \%$, the highest observed so far for Solar System materials, with very low $\mathrm{Zn}$ concentrations compared to enstatite chondrites of lower metamorphic grades (Moynier et al. 2011). Recent studies have shown that $\mathrm{Zn}$ isotopes 
are significantly fractionated during evaporation-condensation processes (Moynier et al., 2011). For example, the $\delta^{66} \mathrm{Zn}$ of lunar basalts is $\sim 1 \%$ heavier than average terrestrial basalts and this extent of fractionation is assumed to have occurred during an evaporation event (Paniello et al., 2012a; Day and Moynier, 2014; Kato et al., 2015). A recent study of Day et al. (2017) has shown that $\mathrm{Zn}$ isotopes are indeed fractionated by $\sim 0.5 \%$ /a.m.u. at high temperatures and pressures (locally $>8400 \mathrm{~K}$ and $>8 \mathrm{GPa}$ ) by evaporation during the nuclear deronation at the Trinity test site, USA, following a Rayleigh distillation processes and that $\mathrm{Zn}$ loss could be significant under some conditions. On the other hand, $\mathrm{Zn}$ loss during tektite formation does not exceed $\sim 20 \%$ (this study and Žák et al., 2016) and our Zn (and $\mathrm{Cu}$ ) elemental and isotope data do not fit a simple Rayleigh fractionation process suggesting that evaporation processes taking place during formation of tektites are more complex than during the nuclear detonation.

It has been recognized that most chondrite groups are enriched in ${ }^{63} \mathrm{Cu}$ relative to BSE, with $\delta^{65} \mathrm{Cu}$ values varying from -1.5 to $-0.1 \%$ in carbonaceous chondrites, -0.5 to $+0.1 \%$ in ordinary chondrites and -0.4 to $-0.15 \%$ in enstatite chondrites (Luck et al., 2003; Savage et al., 2015). This observation implies that impact events and accretion processes result in distinct $\mathrm{Cu}$ isotope systematics of distal impact melt ejecta and planetesimals. Furthermore, the new $\delta^{65} \mathrm{Cu}$ values for tektites in this study (up to $12.5 \%$ ) are, to our knowledge, some of the highest ever measured in natural samples. These high values cannot originate from a common natural process; for example, smelting is unable to fractionate $\mathrm{Cu}$ isotopes despite high temperatures applied (Gale et al., 1999; Mattielli et al., 2006). While the new $\mathrm{Zn}$ and $\mathrm{Cu}$ data for tektites may appear to support the evaporation-induced fractionation process (see Moynier et al., 2009a, 2010), the lack of possible parental materials to tektites in these studies did not enable a more exact assessment of alternative processes. The full complement of new data for sediments from the Ries (Table 1) appears to put certain ambiguity on a purely 
evaporative loss of chalcophile elements. This is illustrated in Fig. 4 where Rayleigh fractionation paths are plotted for several starting $\mathrm{Zn}$ and $\mathrm{Cu}$ concentrations in order to mimic the large range in $\mathrm{Zn}$ and $\mathrm{Cu}$ contents of the sedimentary parentage. For $\mathrm{Zn}$, all calculated paths (elemental and binary species) cross-cut the field of moldavite data at a too perpendicular angle, invoking the inability of the Rayleigh process to result in the observed elemental and isotope systematics of $\mathrm{Zn}$. The model also indicates that a singular initial $\mathrm{Zn}$ abundance value may be at odds with natural systems. On the other hand, the $\mathrm{Cu}$ data can be broadly anchored by a Rayleigh fractionation process if the starting $\mathrm{Cu}$ concentration is $\sim 3-4$ ppm. Such a low $\mathrm{Cu}$ content is not excluded from the current data set (Table 1) but we stress that our data set only represents the best available proxy for $\mathrm{Cu}$ systematics of the sedimentary parentage to moldavites and that moldavite melt represents a mixture of a number of chemically diverse sediments.

\subsection{Implications for volatile loss during tektite formation}

The major observations of this study are two-fold: (i) $\mathrm{Zn}$ and $\mathrm{Cu}$ are lost to distinctively different degrees from the assumed sedimentary materials with $\mathrm{Cu}$ loss being significantly more pronounced (up to $95 \%$ ) than $\mathrm{Zn}$ loss ( 10-20\%), calculated from the average $\mathrm{Cu}$ and Zn contents of volatile loss-corrected OSM sediments (von Engelhardt et al., 2005; Žák et al., 2016), and (ii) $\mathrm{Cu}$ isotopes in tektites are significantly more fractionated than $\mathrm{Zn}$ isotopes. These findings are consistent with earlier observations made for tektites (Moynier et al., 2009a, 2010) but are opposite to what has been found for lunar samples where $\mathrm{Zn}$ is significantly more fractionated than $\mathrm{Cu}$ (Moynier et al., 2006). In the model of Moynier et al. (2009a), a velocity field stirs the tektite, while differential evaporation of $\mathrm{Zn}$ isotopes occurs at the surface. If the characteristic evaporation time is slow with regard to the diffusion 
timescale, the system deviates from Rayleigh process because a diffusion-limited regime is established. As a consequence, the magnitude of the $\mathrm{Zn}$ isotope fractionation is reduced for the latter process at a given extent of $\mathrm{Zn}$ loss. The isotope fractionation in a diffusion-limited regime is controlled by the balance between the evaporative flux and the diffusive flux at the diffusion boundary layer.

The role of redox conditions has been suggested by Moynier et al. (2010) and recent experimental study by ( $\mathrm{Ni}$ and Zhang, 2016) provides evidence that monovalent $\mathrm{Cu}$ is significantly more mobile than divalent $\mathrm{Zn}$ in silicate melts, most likely as a consequence of higher chemical diffusivity. This would perhaps imply that oxidation state and chemical makeup of the system prior to impact (which would control the mineralogical host and chemical exchange in the impact plasma) may play a prominent role in fractionating these elements during the impacts. In fact, the volatility of the elements is directly related to the redox conditions (e.g., O’Neill and Palme, 2008). In the gas phase, both $\mathrm{Cu}$ and $\mathrm{Zn}$ will be present as mono-atomic $\mathrm{Cu}_{\mathrm{g}}$ and $\mathrm{Zn}_{\mathrm{g}}$ at a large range of physical conditions (Moynier et al., 2007). On the other hand, in the condensed phase $\mathrm{Cu}$ will be present as $\mathrm{Cu}^{+}$and, therefore, associated to either $1 / 2 \mathrm{~S}$ atom or $1 / 2 \mathrm{O}$ atom as $\mathrm{CuS}_{1 / 2}$ or $\mathrm{CuO}_{1 / 2}$ while $\mathrm{Zn}$ will be present at $\mathrm{Zn}^{2+}$ and associated with one $\mathrm{O}$ atom as $\mathrm{ZnO}$ in silicate minerals. Following a similar approach as applied by O'Neill and Palme (2008), this would indicate that $\mathrm{Cu}$ will become relatively more volatile than $\mathrm{Zn}$ at higher $f_{\mathrm{O}_{2}}$ and would be consistent with observations from this study. Moreover, significant redox-related diffusive loss of $\mathrm{Cu}$ from tektites can be compared with conservative behaviour of Li which belongs to the fastest diffusing elements with associated isotope effects (e.g., Richter et al., 2003) and yet, tektites do not show any kinetic effects on Li (Magna et al., 2011; Rodovská et al., 2016).

In earlier studies, von Engelhardt et al. $(1987,2005)$ proposed that moldavites are early condensates from the plasma of vaporized source materials in which the elements with larger 
ions were preferentially trapped in the condensed silicate melt relative to those with small ionic radii. However, this model of vaporization contradicts the presence of partly unmelted inclusions (baddeleyite) and abundant domains of pure silica glass (lechatelierite in moldavites; Trnka and Houzar, 2002). Konta and Mráz (1975) experimentally stepwise melted a sample of sandy-silty clay and suggested that evaporation of the silicate material caused a significant change in relations between the major oxides compared to the original chemical-physical relations in the source rocks. They also concluded that direct melting of source sediments is unlikely to form tektites and that evaporation-condensation process should be taken into account. This would require a significant part of the tektite material to have been converted to plasma and re-condensed during rapid cooling. The recent model of moldavite formation (Žák et al., 2016) is based on fragmentation of tektite melt due to separation of volatiles (i.e., $\mathrm{H}_{2} \mathrm{O}, \mathrm{CO}_{2}, \mathrm{CO}$ ) during adiabatic decompression of the ejected matter, followed by coalescence of molten glass droplets to larger tektite bodies. The temperature, at which the individual moldavite bodies were formed, was in the range between the melting temperature of moldavite glass and the melting temperature of lechatelierite, roughly between $\sim 1100$ and $\sim 1713^{\circ} \mathrm{C}$. However, this temperature range is too high for both $\mathrm{Zn}$ and $\mathrm{Cu}$ to condense. Therefore, the process of element loss, instead of condensation, should perhaps be considered for elements with $\mathrm{T}_{\mathrm{c}}$ lower than that of potassium or rubidium, both of which would unlikely to be condensed on a hot glass.

In addition to these observations, we offer further additional physical factors that may help elucidate the $\mathrm{Cu}-\mathrm{Zn}$ elemental and isotope systematics during the impacts. We note, however, that no experimental data exist for relevant impact and post-impact conditions. It could be that electromagnetic properties of ejected particles may come into play. Monovalent and divalent $\mathrm{Cu}$ differ in magnetic properties whereby $\mathrm{Cu}(\mathrm{I})$ is diamagnetic and $\mathrm{Cu}(\mathrm{II})$ is paramagnetic. Electric charges are generated in particle clouds (Pähtz et al., 2010) but it is not 
clear at present, whether such an effect may impart separation of $\mathrm{Cu}$ isotopes in the transient plasma/overheated melt stage of the matter. Furthermore, Fe-group elements can readily form

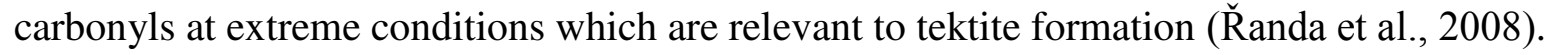

Organic matter was present at the impact site and formation of these highly volatile organometallic compounds cannot be excluded at some stages of the impact process and subsequent p-T relaxation (Cody et al., 2000). Žák et al. (2016) noted that Fe and Cu belong to the few elements that display a large extent of depletion in moldavites relative to possible precursor materials and it remains to be tested whether organometallic compounds may fractionate isotope systems of some other transitional metals to a resolved degree of confidence. Preliminary experimental data of Wiesli et al. (2007) have hinted at marginal Fe isotope fractionation of liquid and vapor Fe-pentacarbonyl. However, only further experimental work can provide new limitations to the behavior of stable isotope systems at extreme conditions.

\section{Conclusions} distinctly enriched in the heavy $\mathrm{Zn}$ and $\mathrm{Cu}$ isotopes relative to their possible parent sedimentary sources with $\mathrm{Cu}$ isotope fractionation in tektites being significantly more pronounced than that of $\mathrm{Zn}$. The origin of this is unclear at present but redox transition of divalent to monovalent $\mathrm{Cu}$ appears to be the dominant factor, resulting in strikingly different diffusivities of $\mathrm{Cu}^{+}$and $\mathrm{Zn}^{2+}$ in tektite melts. It could also be potentially related to formation of volatile carbonyls, or perhaps to different electromagnetic properties of monovalent and divalent $\mathrm{Cu}$. Clay fractions isolated from bulk sediments are uniformly enriched in $\mathrm{Cu}$ and $\mathrm{Zn}$ relative to the corresponding bulk sediments despite the compositional diversity of the latter. 
The clay minerals of the Ries sediments cannot form a major part of the moldavite melts because they are enriched in light $\mathrm{Zn}$ isotopes. The karst sediments show distinctly higher $\mathrm{Zn}$ and $\mathrm{Cu}$ contents paralleled by elevated abundances of $\mathrm{Al}$ and $\mathrm{Fe}$, and cannot thus be a major lithological composition for moldavites, perhaps with the exception of the Cheb Basin moldavites, where participation of karst-like residual soils in the ultimate source of moldavites is probable. Rayleigh distillation process appears to be incapable of generating the observed $\mathrm{Zn}$ and $\mathrm{Cu}$ isotope variability in tektites although no singular starting composition should be applied, considering a possible range in chemistry of parent sediments of tektites. From the Zn triple-isotope plot it follows that kinetic effects may become important for hightemperature processed matter while equilibrium processes apply to low-temperature samples, although sizeable difference could only become apparent at high values of $\delta^{66} \mathrm{Zn}$ and $\delta^{68} \mathrm{Zn}$. The opposite sense of magnitudes of $\mathrm{Zn}$ and $\mathrm{Cu}$ isotope fractionation in tektites versus lunar samples invokes an important role of oxygen and redox processes in general in inducing isotope fractionation of some chalcophile elements whereas other processes apply for oxygendevoid environments.

Acknowledgements - We thank M. Trnka for some moldavite samples, Z. ̌̌anda, J. Mizera, L. Strnad and L. Dziková for chemical characterization, and M. Št’astný for isolation of clay size fractions. Comments by Dominik Hezel, Yuri Amelin, and two anonymous persons on an earlier version of the manuscript improved significantly the clarity of the text. We are grateful to Sheng-Ao Liu and Asish Basu for reviews and Christian Koeberl for editorial handling. This study has been funded through the Czech Science Foundation project 13-22351S. Paul Savage was supported by the Marie Curie IOF 'Isovolc'. Frederic Moynier is grateful to the European Research Council under the European Community's H2020 framework 
program/ERC grant agreement \# 637503 (Pristine) and the Agence Nationale de la Recherche

580 for a chaire d'Excellence Sorbonne Paris Cité (IDEX13C445), and for the UnivEarthS Labex program (ANR-10-LABX-0023 and ANR-11-IDEX-0005-02). Parts of this work were supported by IPGP multidisciplinary program PARI, and by Region Île-de-France SESAME Grant no. 12015908. The authors declare no conflicts of interest. 


\begin{tabular}{|c|c|c|c|c|c|c|c|c|c|c|c|c|}
\hline & Petrographic description & $\mathrm{Zn}(\mathrm{ppm})$ & $\begin{array}{c}\delta^{66} \mathrm{Zn} \\
(\%)\end{array}$ & 2SD & $\begin{array}{c}\delta^{67} \mathrm{Zn} \\
(\%)\end{array}$ & 2SD & $\begin{array}{c}\delta^{68} \mathrm{Zn} \\
(\%)\end{array}$ & 2SD & $\begin{array}{c}\mathrm{Cu} \\
(\mathrm{ppm})\end{array}$ & $\begin{array}{c}\delta^{65} \mathrm{Cu} \\
(\%)\end{array}$ & 2SD & $\begin{aligned} \mathrm{Al}_{2} \mathrm{O}_{3} \\
(\text { wt. } \%)^{\text {a }}\end{aligned}$ \\
\hline \multicolumn{13}{|l|}{ Ries area } \\
\hline \multirow[t]{2}{*}{$1 \mathrm{UTZ}$} & Unterzell; OSM, clay-rich ("bentonite clay") & 81.8 & 0.31 & 0.08 & 0.40 & 0.36 & 0.57 & 0.11 & 17.4 & 0.00 & 0.03 & 13.8 \\
\hline & clay fraction & 93.9 & -0.52 & 0.08 & -0.74 & 0.07 & -1.01 & 0.16 & 26.9 & 0.21 & 0.01 & - \\
\hline 2 UTZ & Unterzell; OSM, clay- and carbonate-rich & 37.9 & 0.09 & 0.10 & 0.24 & 0.10 & 0.22 & 0.12 & 7.5 & 0.29 & 0.04 & 9.34 \\
\hline 3 UTZ & Unterzell; OSM; quartz-dominated fine-grained sand & 19.2 & 0.28 & 0.13 & 0.37 & 0.32 & 0.47 & 0.21 & 3.2 & -0.33 & 0.02 & 5.07 \\
\hline 4 UTZ & Unterzell; OSM, silty-sandy layer & 42.0 & 0.11 & 0.07 & 0.26 & 0.12 & 0.25 & 0.14 & 5.5 & -0.11 & 0.07 & 9.72 \\
\hline $5 \mathrm{ZMTH}$ & Ziemetshausen; OSM, sand with carbonate & 18.2 & 0.17 & 0.16 & 0.21 & 0.34 & 0.33 & 0.25 & 2.1 & 0.11 & 0.03 & 5.79 \\
\hline 9 GLM & Guldesmühle; OMM, carbonate and clay-rich sand & 57.5 & 0.04 & 0.03 & 0.14 & 0.06 & 0.11 & 0.08 & 2.7 & -0.15 & 0.02 & 7.79 \\
\hline 10 GLM & $\begin{array}{l}\text { Guldesmühle; OSM, fine-grained sand with clay and } \\
\text { carbonate } \\
\text { clay fraction }\end{array}$ & $\begin{array}{l}108 \\
161\end{array}$ & $\begin{array}{c}0.46 \\
-0.14\end{array}$ & $\begin{array}{l}0.12 \\
0.06\end{array}$ & $\begin{array}{c}0.61 \\
-0.16\end{array}$ & $\begin{array}{l}0.33 \\
0.08\end{array}$ & $\begin{array}{c}0.86 \\
-0.26\end{array}$ & $\begin{array}{l}0.20 \\
0.10\end{array}$ & $\begin{array}{l}35.3 \\
42.2\end{array}$ & $\begin{array}{c}-0.01 \\
0.00\end{array}$ & $\begin{array}{l}0.04 \\
0.01\end{array}$ & $\begin{array}{c}18.8 \\
-\end{array}$ \\
\hline \multirow[t]{3}{*}{$13 \mathrm{BMB}$} & Burgmagerbein; paleokarst depression filled with & & & & & & & & & & & \\
\hline & $\begin{array}{l}\text { Miocene sediments (mainly limestone weathering } \\
\text { residuum) }\end{array}$ & 44.6 & 0.27 & 0.11 & 0.38 & 0.33 & 0.54 & 0.15 & 9.4 & -0.19 & 0.05 & 8.22 \\
\hline & clay fraction & 137 & -0.27 & 0.04 & -0.32 & 0.05 & -0.49 & 0.09 & 21.4 & -0.10 & 0.02 & - \\
\hline \multirow[t]{2}{*}{$14 \mathrm{BMB}$} & Burgmagerbein; paleokarst channels filled with & & & & & & & & & & & \\
\hline & $\begin{array}{l}\text { Oligocene sediments (mainly limestone weathering } \\
\text { residuum) }\end{array}$ & 180 & 0.26 & 0.14 & 0.28 & 0.27 & 0.42 & 0.22 & 32.7 & 0.03 & 0.04 & 24.3 \\
\hline $15 \mathrm{HRD}$ & $\begin{array}{l}\text { Heroldingen; OSM?, clayish carbonate-rich silt to fine- } \\
\text { grained sand }\end{array}$ & 59.9 & 0.08 & 0.07 & 0.16 & 0.14 & 0.17 & 0.17 & 58.0 & -0.30 & 0.03 & 11.5 \\
\hline $16 \mathrm{HRD}$ & Heroldingen; OSM?, white fine-grained quartz sand & 4.6 & -0.05 & 0.04 & -0.04 & 0.07 & -0.10 & 0.06 & 0.82 & -0.44 & 0.02 & 0.95 \\
\hline 23 MHR & Möhren; freshwater oligocene limestone & 66.4 & 0.58 & 0.12 & 0.80 & 0.31 & 1.10 & 0.19 & 12.2 & 0.19 & 0.02 & 7.97 \\
\hline 24 RTS & Rothenstein; clay-rich paleokarst depression fill & 118 & -0.07 & 0.03 & -0.12 & 0.29 & -0.19 & 0.03 & 33.1 & -0.35 & 0.04 & 30.9 \\
\hline 25 RTS & Rothenstein; quartz-rich red depression fill & 186 & 0.32 & 0.03 & 0.43 & 0.29 & 0.56 & 0.09 & 40.0 & -0.17 & 0.02 & 25.2 \\
\hline $26 \mathrm{LMH}$ & Lohrmanshoff; dolomitized limestone & 8.7 & 0.64 & 0.05 & 0.87 & 0.41 & 1.24 & 0.03 & 1.8 & 0.68 & 0.02 & 0.68 \\
\hline $28 \mathrm{ALT}$ & $\begin{array}{l}\text { Altisheim; OSM, quartz-dominated sand with minor } \\
\text { clay and carbonate }\end{array}$ & 33.2 & 0.07 & 0.06 & 0.18 & 0.05 & 0.19 & 0.09 & 3.0 & -0.15 & 0.01 & 5.26 \\
\hline \multicolumn{13}{|l|}{ Moldavites } \\
\hline SBM-11 & South Bohemia & 14.9 & 2.23 & 0.20 & 3.32 & 0.40 & 4.46 & 0.37 & 0.42 & 5.35 & 0.07 & 10.9 \\
\hline SBM-23 & South Bohemia & 30.7 & 1.66 & 0.11 & 2.35 & 0.41 & 3.23 & 0.19 & 1.23 & 5.10 & 0.04 & 9.47 \\
\hline SBM-35 & South Bohemia & 25.9 & 3.20 & 0.11 & 4.69 & 0.37 & 6.28 & 0.20 & 0.63 & 4.82 & 0.05 & 8.50 \\
\hline SBM-44 & South Bohemia & 6.9 & 2.94 & 0.28 & 4.65 & 0.49 & 6.18 & 0.30 & 0.17 & 3.92 & 0.08 & 7.79 \\
\hline SBM-88 & South Bohemia & 34.5 & 1.82 & 0.12 & 2.64 & 0.31 & 3.55 & 0.17 & 1.44 & 5.02 & 0.10 & 12.2 \\
\hline SBM-192 & South Bohemia & 1.85 & 3.30 & - & 5.27 & - & 6.95 & - & 0.19 & 2.19 & 0.08 & 8.70 \\
\hline MM-60 & Moravia & 18.8 & 2.74 & 0.16 & 4.05 & 0.39 & 5.40 & 0.25 & 0.62 & 8.81 & 0.06 & 11.2 \\
\hline MM-67 & Moravia & 7.3 & 2.11 & 0.05 & 3.08 & 0.63 & 4.22 & 0.26 & 0.75 & 5.77 & 0.04 & 10.5 \\
\hline CHBM-5 & Cheb Basin & 108 & 1.96 & 0.15 & 2.86 & 0.28 & 3.82 & 0.23 & 2.86 & 1.62 & 0.04 & 8.70 \\
\hline CHBM-6 & Cheb Basin & 71.3 & 3.65 & 0.10 & 5.38 & 0.26 & 7.16 & 0.14 & 1.27 & 4.21 & 0.18 & 10.2 \\
\hline
\end{tabular}




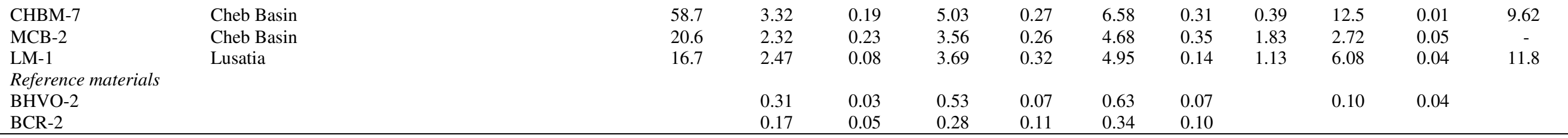

A double-pass quartz spray chamber combined with a $100 \mu \mathrm{L} / \mathrm{min}$ nebulizer was used. Typical signals of $\sim 3 \mathrm{~V}$ for ${ }^{64} \mathrm{Zn}$ and $\sim 10 \mathrm{~V}$ for ${ }^{65} \mathrm{Cu}$ were achieved. For $\mathrm{Zn}$, isobaric interference at mass 64 from $\mathrm{Ni}$ was found negligible by monitoring ${ }^{62} \mathrm{Ni}$ signal $\left(<8 \times 10^{-5} \mathrm{~V}\right)$ and assuming natural Ni isotope composition; levels of $\mathrm{Ga}$ and $\mathrm{Cu}$ were always lower than $2 \mathrm{mV}$ and $20 \mathrm{mV}$, respectively.

A single measurement has only been performed for moldavite SBM-192 due to extremely low Zn content and a limited sample mass available for analysis.

${ }^{a} \mathrm{Al}_{2} \mathrm{O}_{3}$ contents from Žák et al. (2016), save for 26 LMH (this study; recalculated to volatile-free basis according to Žák et al., 2016). 


\begin{tabular}{|c|c|c|c|c|c|c|}
\hline & $a$ & $\mathrm{~L}$ & $\mathrm{U}$ & $b$ & $\mathrm{~L}$ & $\mathrm{U}$ \\
\hline \multicolumn{7}{|c|}{ SMATR, major axis (MA) regression } \\
\hline$S$ & 0.0029 & -0.0296 & 0.0353 & 1.9077 & 1.8038 & 2.0214 \\
\hline M & -0.1620 & -0.5788 & 0.2548 & 2.0658 & 1.9184 & 2.2325 \\
\hline M1 & -0.0350 & -0.3846 & 0.3147 & 2.0062 & 1.8788 & 2.1480 \\
\hline M2 & 0.0450 & -0.1533 & 0.2433 & 1.9629 & 1.8882 & 2.0424 \\
\hline $\mathrm{T}$ & 0.0486 & -0.1732 & 0.2705 & 2.0934 & 1.9651 & 2.2360 \\
\hline \multicolumn{7}{|c|}{ SMATR, MA, zero intercept (line forced through origin) } \\
\hline S & 0 & & & 1.9149 & 1.8468 & 1.9870 \\
\hline M & 0 & & & 2.0068 & 1.9727 & 2.0419 \\
\hline M1 & 0 & & & 1.9932 & 1.9642 & 2.0228 \\
\hline M2 & 0 & & & 1.9798 & 1.9622 & 1.9977 \\
\hline $\mathrm{T}$ & 0 & & & 2.1208 & 2.0708 & 2.1728 \\
\hline \multicolumn{7}{|c|}{ Bootstrap, MA with resampled residuals } \\
\hline S & 0.0027 & -0.0268 & 0.2840 & 1.9087 & 1.8171 & 2.0024 \\
\hline M & -0.1665 & -0.4993 & 0.1716 & 2.0674 & 1.9462 & 2.2029 \\
\hline $\mathrm{T}$ & 0.0468 & -0.1506 & 0.2445 & 2.0946 & 1.9753 & 2.2190 \\
\hline
\end{tabular}

Lines fitted to $\mathrm{Zn}$ isotope data. Intercepts $(a)$, slopes $(b)$ and their lower (L) and upper (U) 95\% confidence limits, for sediments $(\mathrm{S})$, moldavites $(\mathrm{M})$ and other tektites $(\mathrm{T})$. The groups M1 and M2 are cleaned M data (see text for explanation). 


\section{REFERENCES}

Albarède F. (2004) The stable isotope geochemistry of copper and zinc. Reviews in Mineralogy and Geochemistry 55:409-427.

Albarède F., Bunch T. E., Moynier F. and Douchet C. 2007. Isotope fractionation during impact. Earth versus the moon (abstract). Meteoritics \& Planetary Science 42:A11.

Archer C. and Vance D. 2004. Mass discrimination correction in multiple-collector plasma source mass spectrometry: an example using $\mathrm{Cu}$ and $\mathrm{Zn}$ isotopes. Journal of Analytical Atomic Spectrometry 19:656-665.

Artemieva N. 2008. High-velocity impact ejecta: Tektites and martian meteorites. Catastrophic Events Caused by Cosm. Objects, edited by Adushkin V. and Nemchinov I. 8:267-289.

Barrat J. A., Zanda B., Moynier F., Bollinger C., Liorzou C. and Bayon G. 2012. Geochemistry of CI chondrites: Major and trace elements, and $\mathrm{Cu}$ and $\mathrm{Zn}$ isotopes. Geochimica et. Cosmochimica Acta 83:79-92.

Bigalke M., Weyer S. and Wilcke W. 2011. Stable Cu isotope fractionation in soils during oxic weathering and podzolization. Geochimica et Cosmochimica Acta 75:3119-3134.

Blum J. D., Papanastassiou D. A., Koeberl C. and Wasserburg G. J. 1992. Neodymium and strontium isotopic study of Australasian tektites: New constraints on the provenance and age of target materials. Geochimica et Cosmochimica Acta 56:483-492.

Bouška V., Benada J., Řanda Z. and Kuncíŕ J. 1973. Geochemical evidence for the origin of moldavites. Geochimica et Cosmochimica Acta 37:121-131.

Buchner E., Schwarz W. H., Schmieder M. and Trieloff M. 2010. Establishing a 14.6 \pm 0.2 Ma age for the Nördlinger Ries impact (Germany) - a prime example for concordant isotopic ages from various dating materials. Meteoritics \& Planetary Science 45:662-674.

Chappell B. W. and White A. J. R. 1992. I- and S-type granites in the Lachlan Fold Belt. Transactions of the Royal Society of Edinburgh-Earth Sciences 83:1-26.

Chen H., Savage P. S., Teng F. Z., Helz R. T. and Moynier F. 2013. Zinc isotope fractionation during magmatic differentiation and the isotopic composition of the bulk Earth. Earth and Planetary Science Letters. 369370:34-42.

Cody G. D., Boctor N. Z., Filley T. R., Hazen R. M., Scott J. H., Sharma A. and Yoder H. S. 2000. Primordial carbonylated iron-sulfur compounds and the synthesis of pyruvate. Science 289:1337-1340.

Day J. M. D. and Moynier F. 2014. Evaporative fractionation of volatile stable isotopes and their bearing on the origin of the Moon. Philosophical Transaction of the Royal Society of London A 372:20130259.

Day J. M. D., Moynier F., Meshik A. P., Pradivtseva O. V. and Petit D. R. 2017. Evaporative fractionation of zinc during the first nuclear detonation. Science Advances 3: e1602668.

Do Y. and Park H. I. 2011. A study on adsorption of $\mathrm{Pb}, \mathrm{Cu}, \mathrm{Zn}$ and $\mathrm{Cd}$ onto natural clay. International Journal of Environmental Research 5:413-424.

Doucet L. S., Mattielli N., Ionov D. A., Debouge W. and Golovin A. V. 2016. Zn isotopic heterogenity in the mantle: A melting control? Earth and Planetary Science Letters 451:232-240.

Dressler B. O. and Reimold W. U. 2001. Terrestrial impact melt rocks and glasses. Earth-Science Reviews 56:205-284. 
Dunlap R. A., Eelman D. A. and MacKay G. R. 1998. A Mössbauer effect investigation of correlated hyperfine parameters in natural glasses (tektites). Journal of Non-Crystalline Solids 223:141-146.

Engelhardt W. von, Luft E., Arndt J., Schockt H. and Welskirchnert W. 1987. Origin of moldavites. Geochimica et Cosmochimica Acta 51:1425-1443.

Engelhardt W. von, Berthold C., Wenzel T. and Dehner T. 2005. Chemistry, small-scale inhomogeneity, and formation of moldavites as condensates from sands vaporized by the Ries impact. Geochimica et Cosmochimica Acta 69:5611-5626.

Falster D. S., Warton D. I. and Wright I. J. 2006. SMATR: Standardised major axis tests and routines, ver 2.0.http://www.bio.mq.edu.au/ecology/SMATR/.

Fernandez A. and Borrok D. M. 2009. Fractionation of Cu, Fe, and Zn isotopes during the oxidative weathering of sulfide-rich rocks. Chemical Geology 264:1-12.

Gale N. H., Woodhead A. P., Stos-Gale Z. A., Walder A. and Bowen I. 1999. Natural variations detected in the isotopic composition of copper: possible applications to archaeology and geochemistry. International Journal of Mass Spectrometry 184:1-9.

Guinoiseau D., Gélabert A., Moureau J., Louvat P. and Benedetti M. F. 2016. Zn isotope fractionation during sorption onto kaolinite. Environ. Sci. Technol. 50:1844-1852.

Hall A. 1975. Regional variation in the crustal abundance of minor elements: evidence from the granites of Sardinia. Mineralogical Magazine 40:293-301.

Helios-Rybicka E. and Wójcik R. 2012. Competitive sorption/desorption of $\mathrm{Zn}, \mathrm{Cd}, \mathrm{Pb}, \mathrm{Ni}, \mathrm{Cu}$, and $\mathrm{Cr}$ by claybearing mining wastes. Applied Clay Science 65-66:6-13.

Herzog G. F., Alexander C. M. O. D., Berger E. L., Delaney J. S. and Glass B. P. 2008. Potassium isotope abundances in Australasian tektites and microtektites. Meteoritics \& Planetary Science 43:1641-1657.

Hörz F., Ostertag R. and Rainey D. A. 1983. Bunte Breccia of the Ries : Continuous deposits of large impact craters. Reviews of Geophysics 21:1667-1725.

Humayun M. and Clayton R. N. 1995. Potassium isotope cosmochemistry: Genetic implications of volatile element depletion. Geochimica et Cosmochimica Acta 59:2131-2148.

Jeng A. S. 1992. Weathering of some Norwegian alum shales, 2: Laboratory simulations to study the influence of aging, acidification and liming on heavy metal release. Acta Agricultur. Scandinavica Section B-Soil Plant Science, $42: 76-87$

Kato C., Moynier F., Valdes M. C., Dhaliwal J. K. and Day J. M. D. 2015. Extensive volatile loss during formation and differentation of the Moon. Nature Communications 6:7617.

King P. L., White A. J. R., Chappell B. W. and Allen C. M. 1997. Characterization and origin of aluminous Atype granites from the Lachlan Fold Belt, Southeastern Australia. Journal of Petrology 38:371-391.

Koeberl C. 1992. Geochemistry and origin of Muong Nong-type tektites. Geochimica et Cosmochimica Acta 56:1033-1064.

Koeberl C. 1994. Tektite origin by hypervelocity asteroidal or cometary impact. In Large Meteorite Impacts and Planetary Evolution, edited by Dressler B. O., Grieve R. A. F., and Sharpton V. L. Geological Society of America Special Paper 293:133-151.

Koeberl C. 2014. The geochemistry and cosmochemistry of impacts. In Treatise on Geochemistry, $2^{\text {nd }}$ Ed., vol. 2; Edited by Davis A.M.Oxford: Elsevier. pp. 73-118. 
Koeberl C. and Fredriksson K. 1986. Impact glasses from Zhamanshin crater (U.S.S.R.): chemical composition and discussion of origin. Earth and Planetary Science Letters 78:80-88.

Koeberl C., Bottomley R., Glass B. P. and Storzer D. 1997. Geochemistry and age of Ivory Coast tektites and microtektites. Geochimica et Cosmochimica Acta 61:1745-1772.

Koeberl C., Reimold W.U., Blum J. D. and Chamberlain C. P. 1998. Petrology and geochemistry of target rocks from the Bosumtwi impact structure, Ghana, and comparison with ivory Coast tektites. Geochimica et Cosmochimica Acta 62:2179-2196.

Konta J. and Mráz L. 1975. Volatility of oxides from silicate melt and the origin of moldavites. Mineral. Mag. 40:70-78.

Li D., Liu S.-A. and Li S. 2015. Copper isotope fractionation during adsorption onto kaolinite: Experimental approach and applications. Chemical Geology 396:74-82.

Li W., Jackson S. E., Pearson N. J., Alard O. and Chappell B. W. 2009. The Cu isotopic signature of granites from the Lachlan Fold Belt, SE Australia. Chemical Geology 258:38-49.

Liu S.-A., Huang J., Liu J., Wörner G., Yang W., Tang Y.-J., Chen Y., Tang L., Zheng J. and Li S. 2015. Copper isotopic composition of the silicate Earth. Earth and Planetary Science Letters 427:95-103.

Lodders K. 2003. Solar system abundances and condensation temperatures of the elements. The Astrophysical Journal 591:1220-1247.

Luck J. M., Ben Othman D., Barrat J. A. and Albarede F. 2003. Coupled Cu-63 and O-16 excesses in chondrites. Geochimica et Cosmochimica Acta 67:143-151.

Luft E. 1983. Zur Bildung der Moldavite beim Ries-Impact aus Tertiären Sedimenten. Enke Verlag, Stuttgart.

Lv Y., Liu S.-A., Zhu J.-M. and Li S. 2016. Copper and zinc isotope fractionation during deposition and weathering of highly metalliferous black shales in central China. Chemical Geology 445:24-35.

Magna T., Deutsch A., Mezger K., Skála R., Seitz H. M., Mizera J., Řanda Z. and Adolph L. 2011. Lithium in tektites and impact glasses: Implications for sources, histories and large impacts. Geochimica et Cosmochimica Acta 75:2137-2158.

Maréchal C. N., Télouk P. and Albarède F. 1999. Precise analysis of copper and zinc isotopic compositions by plasma-source mass spectrometry. Chemical Geology 156:251-273.

Maréchal C. N., Nicolas E., Douchet C. and Albarède F. 2000. Abundance of zinc isotopes as a marine biogeochemical tracer. Geochemistry Geophysics Geosystems 1:1999GC-000029.

Mason T. F. D., Weiss D. J., Chapman J. B., Wilkinson J. J., Tessalina S. G., Spiro B., Horstwood M. S. A., Spratt J. and Coles B. J. 2005. Zn and Cu isotopic variability in the Alexandrinka volcanic-hosted massive sulphide (VHMS) ore deposit, Urals, Russia. Chemical Geology 221:170-187.

Mathur R., Titley S., Barra F., Brantley S., Wilson M., Phillips A., Munizaga F., Maksaev V., Vervoort J. and Hart G. 2009. Exploration potential of $\mathrm{Cu}$ isotope fractionation in porphyry copper deposits. J. Geochem. Explor. 102:1-6.

Mathur R., Jin L., Prush V., Paul J., Ebersole C., Fornadel A., Williams J. Z. and Brantley S. 2012. Cu isotopes and concentrations during weathering of black shale of the Marcellus Formation, Huntingdon County, Pennsylvania (USA). Chemical Geology 304-305:175-184. 
Mattielli N., Rimetz J., Petit J., Perdrix E., Deboudt K., Flament P. and Weis D. 2006. Zn-Cu isotopic study and speciation of airborne metal particles within a 5-km zone of a lead/zinc smelter. Geochimica et Cosmochimica Acta 70:A401.

McDonough W. F. and Sun S. 1995. The composition of the Earth. Chemical Geology 120:223-253.

Meisel T., Lange J.-M. and Krähenbühl U. 1997. The chemical variation of moldavite tektites: Simple mixing of terrestrial sediments. Meteoritics \& Planetary Science 32:493-502.

Moeller K., Schoenberg R., Pedersen R.-B., Weiss D. and Dong S. 2012. Calibration of the new certified reference materials ERM-AE633 and ERM-AE647 for copper and IRMM-3702 for zinc isotope amount ratio determinations. Geostandards and geoanalytical research 36:177-199.

Moynier F., Albarède F. and Herzog G. F. 2006. Isotopic composition of zinc, copper, and iron in lunar samples. Geochimica et Cosmochimica Acta 70:6103-6117.

Moynier F., Blichert-Toft J., Telouk P., Luck J.-M. and Albarède F. 2007. Comparative stable isotope geochemistry of $\mathrm{Ni}, \mathrm{Cu}, \mathrm{Zn}$, and $\mathrm{Fe}$ in chondrites and iron meteorites. Geochimica et Cosmochimica Acta $71: 4365-4379$.

Moynier F., Beck P., Jourdan F., Yin Q. Z., Reimold U. and Koeberl C. 2009a. Isotopic fractionation of zinc in tektites. Earth and Planetary Science Letters 277:482-489.

Moynier F., Koeberl C., Beck P., Jourdan F. and Telouk P. 2010. Isotopic fractionation of Cu in tektites. Geochimica et Cosmochimica Acta 74:799-807.

Moynier F., Paniello R. C., Gounelle M., Albarède F., Beck P., Podosek F. and Zanda B. 2011. Nature of volatile depletion and genetic relationships in enstatite chondrites and aubrites inferred from $\mathrm{Zn}$ isotopes. Geochimica et Cosmochimica Acta 75:297-307.

Moynier F. and Le Borgne M. 2015. High precision zinc isotopic measurements applied to mouse organs. JoveJournal of Visualized Experiments, e52479.

Moynier F., Vance D., Toshiyuki F. and Savage P. 2017. The isotope geochemistry of zinc and copper. Reviews in Mineralogy and Geochem.istry 82:543-600.

Ni P. and Zhang Y. 2016. Cu diffusion in a basaltic melt. American Mineralogist 101:1474-1482.

O’Neill H. S. C. and Palme H. 2008. Collisional erosion and the non-chondritic composition of the terrestrial planets. Philosophical Transactions of the Royal Society A. 366:4205-4238.

Pähtz T., Herrmann H. J. and Shinbrot T. 2010. Why do particle clouds generate electric charges? Nature Physics 6:364-368.

Palme H. and O’Neill H. S. C. 2014. Cosmochemical estimates of mantle composition. In: Treatise on Geochemistry, $2^{\text {nd }}$ Edn. vol. 3, Edited by Carlson R. W.). Elsevier, pp. 1-39.

Paniello R. C., Day J. M. D. and Moynier F. 2012a. Zinc isotopic evidence for the origin of the Moon. Nature 490:376-379.

Paniello R. C., Moynier F., Beck P., Barrat J.-A., Podosek F. A. and Pichat S. 2012b. Zinc isotopes in HEDs: Clues to the formation of 4-Vesta, and the unique composition of Pecora Escarpment 82502. Geochimica et Cosmochimica Acta 86:76-87.

Pichat S., Douchet C. and Albarède F. 2003. Zinc isotope variations in deep-sea carbonates from the eastern equatorial Pacific over the last $175 \mathrm{ka}$. Earth and Planetary Science Letters 210:167-178. 
Pohl J., Stöffler D., Gall H. and Ernstson K. 1977. The Ries impact crater. Impact Explos. Cratering, $343-404$.

Richter F. M., Davis A. M., DePaolo D. J. and Watson E. B. 2003. Isotope fractionation by chemical diffusion between molten basalt and rhyolite. Geochimica et Cosmochimica Acta 67:3905-3923.

Rodovská Z., Magna T., Žák K., Skála R., Brachaniec T. and Visscher C. 2016. The fate of moderately volatile elements in impact events-Lithium connection between the Ries sediments and central European tektites. Meteoritics \& Planetary Science 51:2403-2415.

Rouxel O., Fouquet Y. and Ludden J. N. 2004. Copper isotope systematics of the Lucky Strike, Rainbow, and Logatchev sea-floor hydrothermal fields on the Mid-Atlantic Ridge. Economic Geology and the Bulletin of the Society of Economic Geologists 99:585-600.

Rudnick R. L. and Gao S. 2014. Composition of the continental crust. In: Treatise on Geochemistry, $2^{\text {nd }}$ Ed., vol. 4, edited by Rudnick R.L.. Elsevier. pp. 1-51.

Řanda Z., Mizera J., Frána J. and Kučera J. 2008. Geochemical characterization of moldavites from a new locality, the Cheb Basin, Czech Republic. Meteoritics \& Planetary Science 43:461-467.

Řanda Z., Mizera J., Žák K., Skála. and Kameník J. 2014. Activation analysis in geochemical characterization of sediments related to the Ries impact crater. In $4^{\text {th }}$ Int. Nucl. Chem. Congress, 14-19 September 2014, Sao Paulo, Brazil, Program and Abstract Book, p. 297.

Savage P. S., Moynier F., Chen H., Siebert J., Badro J., Puchtel I. S. and Shofner G. 2015. Copper isotope evidence for large-scale sulphide fractionation during Earth's differentiation. Geochemical Perspectives Letters 1:53-64.

Schwarz W. H. and Lippolt H. J. 2014. ${ }^{40} \mathrm{Ar}^{39} \mathrm{Ar}$ step-heating of impact glasses from the Nördlinger Ries impact crater - Implications on excess argon in impact melts and tektites. Meteoritics \& Planetary Science 49:10231036.

Shaw H. F. and Wasserburg G. J. 1982. Age and provenance of the target materials for tektites and possible impactites as inferred from Sm-Nd and Rb-Sr systematics. Earth and Planetary Science Letters 60:155-177.

Skála R., Strnad L., McCammon C. and Čada M. 2009. Moldavites from the Cheb Basin, Czech Republic. Geochimica et Cosmochimica Acta 73:1145-1179.

Skála R., Mizera J., Řanda Z., Žák K. and Dzíková L. 2010. Statistical evaluation of a set of geochemical data from a large collection of moldavites measured by INAA and IPAA. Meteoritics \& Planetary Science 45:A190.

Sossi P. A., Halverson G. P., Nebel O. and Eggins S. M. 2014. Combined separation of Cu, Fe and Zn from rock matrices and improved analytical protocols for stable isotope determination. Geostandards and Geoanalytical Research 39:129-149.

Stöffler D., Artemieva N. A., Wünnemann K., Reimold W. U., Jacob J., Hansen B. K. and Summerson I. A. T. 2013. Ries crater and suevite revisited-Observations and modeling. Part I: Observations. Meteoritics \& Planetary Science 48:515-589.

Trnka M. and Houzar S. 2002. Moldavites : a review. Bulletin of the Czech Geological Survey 77:283-302.

Vance D., Archer C., Bermin J., Perkins J., Statham P. J., Lohan M. C., Ellwood M. J. and Mills R. A. 2008. The copper isotope geochemistry of rivers and the oceans. Earth and Planetary Science Letters 274:204213. Wang K. and Jacobsen S. B. 2016. Potassium isotopic evidence for a high-energy giant impact origin of the Moon. Nature 538:487-490. 
Wang Z.-Z., Liu S.-A., Liu J., Huang J., Xiao Y., Chu Z.-Y., Zhao X.-M. and Tang L. 2017. Zinc isotope fractionation during mantle melting and constraints on the $\mathrm{Zn}$ isotope composition of Earth's upper mantle. Geochimica et Cosmochimica Acta, 198:151-167.

Warton D. I., Wright I. J., Falster D. S. and Westoby M. 2006. Bivariate line-fitting methods for allometry. Biological Reviews 81(2):259-291.

Wiesli R. A., Beard B. L., Braterman P. S., Johnson C. M., Saha S. K. and Sinha M. P. 2007. Iron isotope fractionation between liquid and vapor phases of iron pentacarbonyl. Talanta 71:90-96.

Wombacher F., Rehkämper M., Mezger K. and Münker C. 2003. Stable isotope compositions of cadmium in geological materials and meteorites determined by multiple-collector ICPMS. Geochimica et Cosmochimica Acta 67:4639-4654.

Young E. D. and Galy A. 2004. The isotope geochemistry and cosmochemistry of magnesium. Reviews in Mineralogy and Geochemistry 55:197-230.

Žák K., Skála R., Řanda Z. and Mizera J. 2012. A review of volatile compounds in tektites, and carbon content and isotopic composition of moldavite glass. Meteoritics \& Planetary Science 47:1010-1028.

Žák K., Skála R., Řanda Z., Mizera J., Heissig K., Ackerman L., Ďurišová J., Jonášová Š., Kameník J. and Magna T. 2016. Chemistry of Tertiary sediments in the surroundings of the Ries impact structure and moldavite formation revisited. Geochimica et Cosmochimica Acta 179:287-311. 


\section{Figure captions}

\section{Figure 1}

Copper vs. Zn concentrations (a) and isotope compositions (b) in central European tektites and sediments from the Ries area. Clay fractions are also plotted. Copper shows significantly larger scatter in isotope compositions relative to $\mathrm{Zn}$. The $\mathrm{Cu}$ and $\mathrm{Zn}$ elemental and isotope data for other tektites (gray field) and moldavites (dashed area) are from Moynier et al. (2009a, 2010).

\section{Figure 2}

The $\mathrm{Zn}$ contents versus $\mathrm{Al}_{2} \mathrm{O}_{3}$ contents in moldavites and sediments from the Ries area. A broadly positive correlation is observed for sediments whereas tektites show rather uniform $\mathrm{Al}_{2} \mathrm{O}_{3}$ contents at a large range of $\mathrm{Zn}$ abundances. Zinc and $\mathrm{Al}$ data for other tektites and moldavites are given in Moynier et al. (2009a).

\section{Figure 3}

The plot of $\delta^{68} \mathrm{Zn}$ versus $\delta^{66} \mathrm{Zn}$ for moldavites, sediments and clay fractions. The slopes for different groups (sediments and moldavites - this study, tektites - Moynier et al., 2009a) imply similar processes of $\mathrm{Zn}$ isotope fractionation for samples modified at high temperatures (kinetic effects) and for those that underwent only low-temperature consolidation (equilibrium effects); see main text for further discussion. Dashed circle denotes australite 5772 core (Moynier et al., 2009a) which is clearly off the linear trend and also shows peculiar $\mathrm{Zn}$ enrichment (265 ppm). Samples SBM-44 and SBM-192 are marked and were discussed in terms of statistical evaluation (see Section 4.1).

\section{Figure 4}

The plot of $\mathrm{Zn}(\mathrm{a})$ and $\mathrm{Cu}(\mathrm{b})$ abundances and isotope compositions versus possible paths of a Rayleigh distillation process. Several starting points for $\mathrm{Zn}$ and $\mathrm{Cu}$ abundance were used to illustrate the concentration range of these elements in sedimentary materials of the Ries area. 
Rayleigh distillation paths for $\mathrm{Cu}(\mathrm{I})$ species are nearly identical to $\mathrm{Cu}$ (II) species and a case for $\mathrm{Cu}_{2} \mathrm{O}$ is only plotted. The primitive upper mantle and the upper continental crust values are from McDonough and Sun (1995) and Rudnick and Gao (2014). 


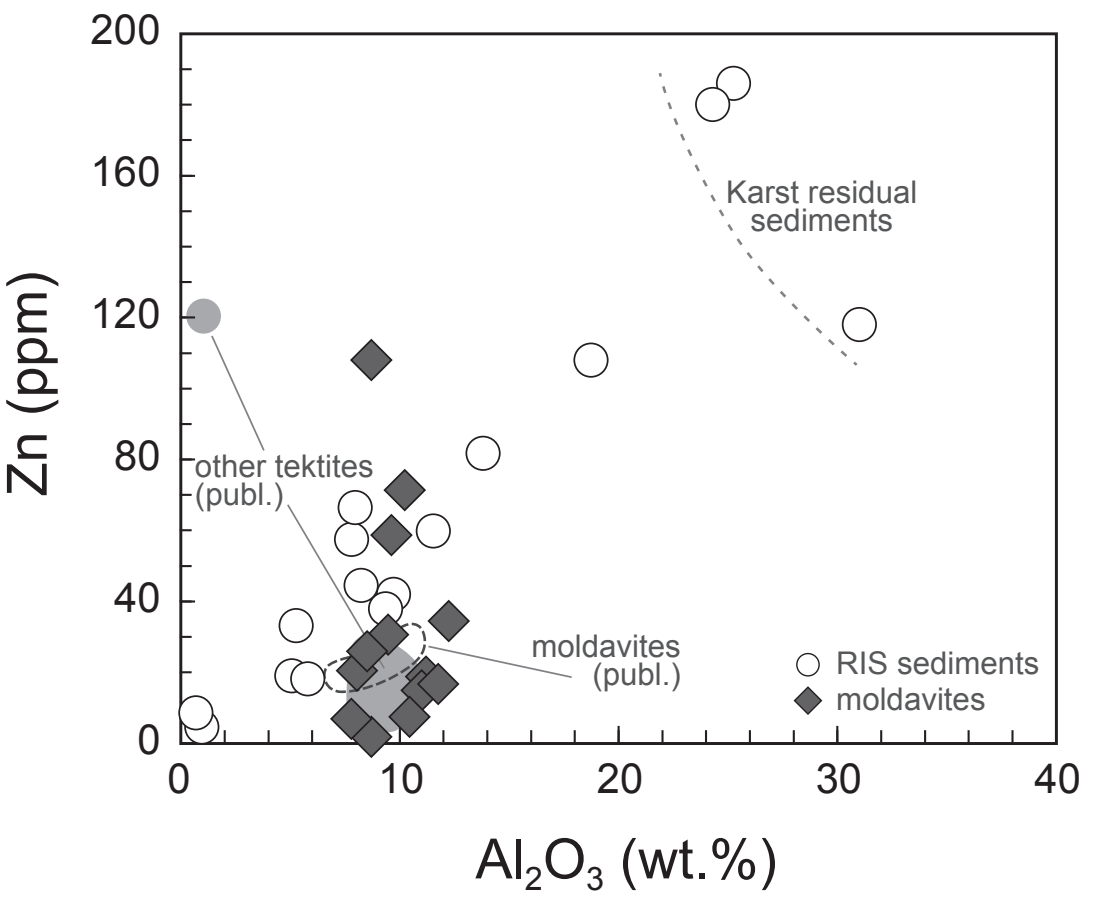




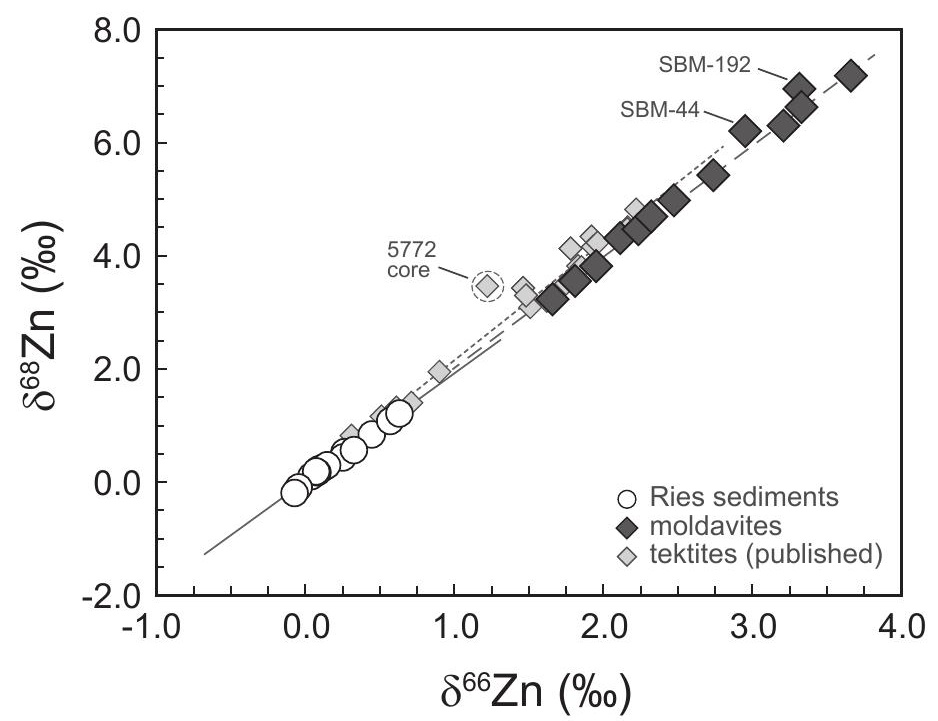


